\title{
AMEAÇA AOS DIREITOS FUNDAMENTAIS E À DEMOCRACIA: A LEI ANTITERROR DO BRASIL
}

\author{
THREAT TO THE FUNDAMENTAL RIGHTS AND DEMOCRACY: BRAZILIAN ANTI-TERROR BILL
}

Eduardo Augusto Salomão Cambi ${ }^{1}$

Felipe Augusto Rodrigues Ambrosio ${ }^{2}$

\begin{abstract}
Resumo: Com o presente trabalho procurou-se demonstrar as ameaças trazidas pela Lei 13.260/16, de combate ao terrorismo, às manifestações populares e os riscos ao exercício da democracia. $O$ mundo global se vê acometido pelo fenômeno do terrorismo, o qual tem sido apto a desencadear uma paranoia coletiva e uma fobia potencializada, em tempos em que a civilização alcançou um nível e padrão de segurança nunca antes vistos. As alternâncias do conceito de terrorismo se referem a fenômenos tão distintos quanto o exercício do poder, seja pelo medo difundido, pelo grau da violência praticada, seja pela mobilização política, podendo enfraquecer as formas legítimas de reivindicação popular. Buscou-se desvendar, no presente trabalho, como se chega à conclusão de quem é o terrorista, e a influência e marca da globalização nesse processo. Por fim, fez-se uma crítica a como o Estado tem desenvolvido uma política penal e de exceção que fere os direitos humanos e fundamentais. Para se examinar como o terrorismo de Estado deve ser uma preocupação no cenário brasileiro, partiu-se da revisão crítica dos temas centrais, adotaram-se os métodos histórico, tipológico e estruturalista e, enquanto técnica de pesquisa, a documentação indireta e legislativa.
\end{abstract}

Palavras-chave: Globalização. Estado de exceção. Lei 13.260/16. Terrorismo. Manifestações sociais.

\begin{abstract}
This paper aimed to demonstrate how Bill 13.260/16, of terrorism's combat, operates in a dynamic of persecution and seal the popular demonstrations, and represents a risk to the exercise democracy. Currently, the global world is affected by a hysteria caused by the terrorism's phenomenon, which has been able to take collective paranoia and phobia enhanced in times when civilization has achieved a standard and level of security never seen before. The alternations of terrorism concept refer to as diverse phenomena as the exercise of power, both by the widespread fear, by the degree of practiced violence, or by political mobilization, and readily show its weakness as a political instrument and its potential as a revindication tool. It was sought to uncover how it comes to the conclusion of who is the terrorist, and the influence and demarcation of globalization in the process. Finally, it was performed a criticism of how the state is developing a criminal and exception poli$\mathrm{cy}$, which violates the human rights. In order to analyze that state terrorism must be a real concern in the Brazilian scenario, through the critical review, it was adopted the historical, typological and structuralist methods, and, as technical research, the indirect and legislative documentation.
\end{abstract}

Keywords: Globalization. State of exception. Bill 13.260/16. Terrorism. Popular manifestation.

\footnotetext{
1 Pós-doutor em Direito pela Università degli Studi di Pavia (Itália); Doutor em Direito pela Universidade Federal do Paraná; Professor na Universidade Estadual do Norte do Paraná e na Universidade Paranaense; Avenida Manoel Ribas, 711, Centro, 86400-000, Jacarezinho, Paraná, Brasil; eduardocambi@hotmail.com

2 Graduado em Direito pela Universidade Estadual do Norte do Paraná; mestrando em Ciência Jurídica pelo Programa de Pós-Graduação da Universidade Estadual do Norte do Paraná; lipeambrosio@hotmail.com
} 


\section{Introdução}

Os ataques terroristas ocorridos nos últimos anos deixaram clara a existência de riscos impossíveis de serem previstos, fugindo à prevenção estratégica típica da racionalidade tradicional do combate ao inimigo.

Um dos grandes desafios do Direito Penal na contemporaneidade é ocupar-se de outros bens jurídicos que não se restringem exclusivamente ao Estado-nação ou a determinada comunidade (AZEVEDO; TONETTO, 2016). Os atos de terrorismo revelam uma nova espécie de criminalidade contra a qual o Estado-nação é ainda mais impotente, pois demonstraram a descontinuidade temporal e espacial da violência, bem como comprometem a principal promessa da modernidade: a segurança.

A gestão da criminalidade pelas agências estatais de repressão potencializa medos e torna vulneráveis as conquistas da própria democracia, trazendo retrocessos na cultura e no respeito aos direitos fundamentais.

É preciso ter cautela para não transformar o combate ao terrorismo em uma agenda negativa à proteção dos direitos humanos fundamentais, pois é extremamente perigoso para a democracia quando algo tomado como um risco global é aplicado para reprimir cidadãos que se manifestam por direitos e lutam contra as injustiças impostas pelo sistema econômico pautado no interesse de poucos, os quais rotulam como terrorista aquele que lhe representa algum risco: não à sua integridade, mas a seu patrimônio.

A criação de uma lei antiterrorismo, com um dispositivo legal aberto e vago como o constante no artigo 2o da Lei 13.260/2016, deve ser contextualizada com a proteção dos direitos fundamentais, para não servir de instrumento para coibir manifestações populares e de pensamento.

No Brasil, é preciso estar atento - até mais que para atos praticados por extremistas religiosos - para a atuação do próprio Estado, que se omite e por vezes acaba institucionalizando uma política de violência, tortura e morte, aplicada principalmente contra os segmentos mais vulneráveis da população.

\section{Conceito de terrorismo: dificuldade semântica e ontológica}

Maquiavel (apud MACHIAVELLI, 1982, p. 67) já preconizava que uma das maiores virtudes do governante era a "capacidade de infundir o terror no coração das pessoas sob seu poder." Três séculos mais tarde, a palavra terrorismo acabou surgindo conjugada ao modus operandi dos Estados modernos, tendo como principal referência o ocorrido na França durante a ditadura do Comitê de Saúde Pública liderado por Robespierre entre 1793 e 1794 durante a Revolução Burguesa. Estima-se que, nesse curto período, foram executadas sumariamente 17 mil pessoas, com cerca de 300 mil prisões, muitas vezes sem julgamento ou defesa (FRAGOSO, 1981, p. 14). 
De início, deve ser salientado que, quando se trata da palavra terrorismo, devem ser tomados alguns cuidados para que o termo seja compreendido de forma clara e imparcial, embora, no imaginário popular, sua concepção esteja vinculada ao sentimento de medo. Ao tratar de terrorismo, Fragoso (1981, p. 4) expõe suas diferentes interpretações e adverte que tal expressão apresenta uma conotação pejorativa, sendo comumente usada pelos que estão no poder contra grupos dissidentes, para suscitar temor e hostilidade. Quando se tenta buscar a definição adequada para atos de terrorismo, deve-se ter em mente a dificuldade de se alcançar tal objetivo. Não há um entendimento preciso sobre o que o termo terrorismo abarca, sendo difícil, senão impossível, alcançar-se uma conceituação precisa, ainda mais porque, na contemporaneidade, sua noção vem se tornando cada vez mais complexa.

Fragoso (1981, p. 7), mesmo advertindo da dificuldade e da complexidade de tal tarefa, destaca alguns elementos da conceituação de terrorismo, como a vontade de "impor ou favorecer a difusão de determinadas doutrinas sociais ou políticas", o "emprego de meios capazes de criar estragos consideráveis ou perigo comum", "violência ou ameaça de violência", e "no especial fim de agir, constituído pelo propósito de atentar contra o sistema político-social vigente."

O terrorismo pode ser colocado como um fenômeno de caráter técnico e instrumental, complementando-se com juízos de valor, particularmente negativos, traduzidos no sentimento de horror que o fenômeno inspira. Conforme Crenshaw (2010, p. 27), "terrorismo é um conceito contestável [...] [cujo] uso é em geral subjetivo e pejorativo, empregado com o sentido de condenar um adversário." Por esse motivo, a busca por uma definição jurídica universal tem sido há décadas infrutífera. A autora lembra que as primeiras tentativas de se estabelecer um marco jurídico apontam a 1973, quando a Organização das Nações Unidas (ONU) iniciou seus esforços, os quais já se traduzem em 12 convenções internacionais, além de inúmeras outras normativas nacionais.

Para a Anistia Internacional (2001), os termos "terroristas" e "atos terroristas" na Resolução 1.373 da ONU, adotada pelo Conselho de Segurança em 28 de setembro de 2001, possibilitam interpretações bastante diferentes e facilitam violações aos direitos. É certo que o terrorismo assume uma nova face, tendo como grande marco os atentados de 11 de setembro de 2001 ao complexo predial do World Trade Center, em Nova York. A perda do monopólio da violência pelo Estado fica evidenciada no fato de um reduzido grupo, recrutado e treinado pela organização terrorista internacional Al-Quaeda e liderado pelo saudita Osama Bin Laden, por meio de técnicas de ação violenta, conseguir ter sobrepujado a maior potência global, ainda que por algumas horas e de forma limitada. Tal fato demonstra, ainda, como a dinâmica geopolítica se afastou dos Estados e incluiu novos atores em cena, evidenciando a perda de legitimidade de poder e de recursos, como afirma Hobsbawm (2007, p. 125):

O aumento da violência em geral faz parte do processo de barbarização que tomou força no mundo desde a Primeira Guerra Mundial [...] Seu progresso é bastante notável nos países com Estados fortes e estáveis e instituições políticas liberais (em teoria), em que o discurso público e as instituições políticas distinguem ape- 
nas dois valores absolutos e mutuamente excludentes - a "violência" e a "não-violência". Isto foi uma outra forma de estabelecer a legitimidade do monopólio da força coercitiva por parte do Estado nacional, que acompanhou o desarmamento da população civil nos países desenvolvidos no século XX, com exceção dos Estados Unidos, que, por conseguinte, toleraram um grau maior de violência na prática, embora não em teoria. Desde o final da década de 1960, os Estados perderam em parte esse monopólio de poder e de recursos e perderam também algo mais do sentido de legitimidade que faz com que os cidadãos respeitem a lei. Isso basta para explicar em grande medida o aumento da violência.

Em 1986, o departamento de defesa dos EUA (DEPARTMENT OF DEFENSE, 1986, p. 15) definiu terrorismo como "o uso ou a ameaça do uso de violência premeditada contra indivíduos ou propriedade para impingir medo, com vistas a coagir ou intimidar governos ou sociedades na perseguição de objetivos políticos, ideológicos ou religiosos."

Após os atentados de 11 de setembro de 2001, a legislação estadunidense foi reorientada a partir do Patriot Act (US PATRIOT ACT, 2001, \$2331), assinado em 26 de outubro de 2001, o qual definiu terrorismo como

(a) atos violentos ou ameaçadores à vida humana que são uma violação da lei criminal dos EUA ou de qualquer Estado, ou que pode ser uma violação criminal se cometida na jurisdição dos EUA ou de qualquer Estado; (b) [atos] que tencionem (i) intimidar ou coagir uma população civil, (ii) influenciar a política de um governo por intimidação ou coerção, (iii) afetar a conduta de um governo por meio de destruição em massa, assassinato ou sequestro.

A legislação norte-americana de 2001 procedeu a uma associação direta entre terrorismo e crime, deixando em aberto a possibilidade de classificar uma série indefinida de atos como terroristas. Além disso, menciona as demais legislações que possam existir em outros países do mundo, deixando espaços móveis para a definição de táticas planetárias de combate ao que se definir por terrorismo.

Um compêndio de definições de terrorismo extraído das agências estadunidenses (como o FBI e a CIA), de países aliados dos EUA, como o Reino Unido e a França, ou mesmo as assimiladas pela ONU revelam um conjunto de classificações aproximadas e abertas a interpretações variadas. A ONU, em um esforço de reunir essas definições em uma que pudesse amparar a elaboração de um tratado internacional unificador, formou, em 2002, uma comissão específica composta por representantes dos Estados-membros e especialistas, a qual se dissolveu em 2005 sem conseguir superar as diferenças de opinião entre países ocidentais e árabes (TUMAN, 2010).

Uma das tentativas de unificação da definição foi seguir a legislação estadunidense, visando aos atos que tipificariam o terrorismo como assassinatos seletivos, atentados contra civis e ataques a infraestruturas. A discordância, no entanto, foi generalizada, impedindo que se chegasse a um consenso. Enquanto isso, a guerra ao terror seguia elaborando táticas e colocando-as em prática, legislando no campo das medidas excepcionais - com as suspensões de direitos individuais nos EUA - e abrindo vácuos jurídicos, como o campo de concentração na base naval de Guantánamo, em Cuba (Guantánamo Bay Detention Camp), ou as prisões e voos clandestinos, levando suspeitos 
de terrorismo para a prisão, vindos de muitos pontos do Planeta, contando, para isso, com a colaboração de diversos países (RODRIGUES, 2013, p. 212).

Com a delimitação do terrorismo enquanto fenômeno jurídico e político e da identificação de suas implicações jurídicas no âmbito da sociedade transterritorial, há de se explorar a função que os direitos humanos podem desempenhar entre as nações para o enfrentamento do terrorismo internacional e como as duas temáticas se relacionam. Conceituações vagas, como as apresentadas, devem ser objeto de crítica (HALWANI, 2006). É preciso questionar o que vem a ser terrorismo e a forma como são tomadas as definições do tema. Para se definir o terrorismo, não se pode considerar apenas a visão de um dos lados, ou seja, o da vítima. Ademais, o método para elaborar uma definição menos parcial deve levar em consideração o que é feito e o objetivo imediato do agente, deixando de lado quem é o agente e seu principal e suposto escopo.

Com tal proposta, visa-se questionar a forma como o terrorismo é analisado de modo geral, para se buscar repensar o posicionamento hegemônico, a fim de que exista uma compreensão mais completa e condizente com a realidade global, gerando maior prevenção e proteção contra novos ataques. Importa enfatizar que tais questionamentos não servem para fortalecer a prática do terrorismo, fenômeno extremamente grave e que deve ser estudado em todas as suas vertentes possíveis.

Pode-se questionar se existe uma justificativa moral para os atos terroristas. Nesse sentido, em tese, o terrorismo se justificaria apenas em casos extremos, embora seja muito difícil demonstrar, de forma racional e convincente, que não haveria outra forma menos dolorosa de se fazer o trabalho revolucionário (HALWANI, 2006).

A presença de "alvos inocentes" em relação aos ataques terroristas dificulta um julgamento moral imparcial. Apesar disso, a justificativa moral de qualquer instância do terrorismo poderia se traduzir no alcançamento da justiça com menos e melhores alvos e a menor destruição possível entre todas as alternativas disponíveis (supondo sempre que todas as estratégias de não violência se exauriram). Dessa forma, um ataque se justificaria caso se direcionasse para alvos específicos com o mínimo de destruição e o máximo de vidas preservadas. De qualquer modo, ainda que se busque tal justificativa moral, dificilmente uma ação terrorista, mesmo em casos específicos, encontraria uma fundamentação racional convincente.

A dificuldade em definir terrorismo e a proximidade entre o teor das acusações de terrorista explicitam como não há uma ontologia do terrorista e do terrorismo, eis que não há uma essência que os fie e classifique:

o crime e o terrorismo pelo alto ou por baixo, serão defendidos ou combatidos segundo as circunstâncias históricas, as extensões das forças em lutas ou as mobilidades de conservadores e revolucionários, não podendo ser apanhados por uma teoria da mesma maneira que não sustenta uma ontologia do crime. (PASSETTI, 2006, p. 101). 
Nesse sentido, não se pode esquecer a associação entre "terrorismo" e "crime", realizada no ato patriótico, evidenciando o que analisa Passetti (2006) quanto à ausência de definição essencial dessas categorias, que obedecem aos resultados sempre precários e históricos estabelecidos pelo enfrentamento constante das forças sociais e de suas intencionalidades políticas.

Opera na definição de terrorismo, portanto, um efeito de guerra: o conflito infindável entre verdades em busca de afirmação. Uma guerra cujo triunfo é a sua validação histórica e cuja análise pode ser feita seguindo as indicações da genealogia do poder elaboradas por Foucault (2008a). Desse modo, uma genealogia do terrorismo não interessada em desvelar sua suposta essência ou origem encontraria procedências variadas, tanto na prática dos terrorismos quanto no embate pela concepção de verdades acerca do terrorismo. Tal genealogia do terrorismo encontraria sua ascendência contemporânea no jacobinismo revolucionário francês, enquanto terror de Estado voltado à defesa dos valores universais que se afirmavam, pela força política, como verdades inquestionáveis.

Esses fundamentos emergem, também, nos projetos revolucionários e escatológicos do século XX, cujo ápice teria sido, conforme Foucault (2008a), o stalinismo e o nazismo, que levaram ao paroxismo a guerra das raças inscrita no discurso histórico-político ao preconizar o extermínio da raça ruim (quer fosse sub-raça, quer fosse o contrarrevolucionário) para que a raça superior triunfasse.

\section{A Lei 13.260/2016 e a posição do brasil no contexto geopolítico global}

A utilização do clamor público para justificar medidas de endurecimento político-criminal não é uma questão nova. Ao mesmo tempo em que se fortalece a cultura do medo, vende-se como solução o aumento do controle da população pelos aparelhos repressivos do Estado. Verifica-se essa dinâmica após 13 de novembro de 2015, quando o presidente francês François Hollande tratou de intensificar as ações militares contra a Organização do Estado Islâmico (OEI) e propôs uma reforma constitucional a fim de dar mais poderes ao Executivo.

Mesmo que tais acontecimentos estejam mais distantes da realidade brasileira, a mídia, o governo e a bancada parlamentar conservadora se aproveitaram do episódio para exigir a rápida tramitação e aprovação da Lei 13.260 (BRASIL, 2016), à época projeto de lei do executivo (PLE) 2.016/2015. Percebe-se, destarte, a ausência de reflexão mais profunda sobre a temática do terrorismo no cenário nacional. Mesmo porque, nesta parte do trabalho, o objetivo não é discutir quais os dilemas e soluções da sociedade europeia diante do terrorismo, mas tentar apontar os danos sociais e os perigos das restrições aos direitos fundamentais que a adoção da guerra ao terror pode gerar no Brasil.

Apresentado pelo Executivo na figura da presidente Dilma Vana Rousseff, o Projeto de Lei 2.016/2015 (BRASIL, 2015a), relatado pelo Deputado Federal Arthur Maia (SD-BA), depois de 
emendas parlamentares, passou a enquadrar como terrorismo crimes motivados por "ideologia, xenofobia, religião, discriminação ou preconceito de raça, cor ou etnia [com o] objetivo de intimidar o Estado, organização internacional, pessoa jurídica e provocar terror generalizado na ordem social", prevendo, como sanções, penas de 12 a 30 anos de reclusão, além das correspondentes à ameaça ou à violência.

Em 13 de agosto de 2015, em regime de urgência, o Projeto foi aprovado em primeira votação pela Câmara dos Deputados (2015). Em 28 de outubro de 2015, passou pelo Senado, que o modificou em alguns pontos (BRASIL, 2015b). O Projeto de lei retornou à Câmara que, no dia 24 de fevereiro de 2016, rejeitou o substitutivo do Senado e aprovou a versão votada em agosto de 2015 .

Em 16 de março de 2016, a Presidente Rousseff sancionou a Lei, vetando-a em oito pontos, dos quais dois diziam respeito à definição de atos de terrorismo (PRESIDÊNCIA DA REPÚBLICA, 2016).

O texto aprovado pela Câmara dos Deputados continha uma série de elementos subjetivos, como o conceito de terrorismo, que continuará mudando e se transformando ao longo da história, sempre vinculado às mudanças políticas e econômicas, além de servir aos interesses dos diferentes grupos no poder. Alguns desses elementos abertos e subjetivos foram vetados pela Presidência da República, após forte pressão popular e de movimentos sociais. Contudo, a Lei ainda continua a apresentar defeitos, em razão da sua abstração, generalidade e vulnerabilidade a subjetividades.

A Lei 13.260/2016 aprovada pelo Congresso classificava como atos de terror, no artigo $2^{\circ}, \int 1^{\circ}$, do inc. II, "incendiar, depredar, saquear, destruir ou explodir meios de transporte ou qualquer bem público ou privado." Também previa, no inciso seguinte, serem atos terroristas as ações de "interferir, sabotar ou danificar sistemas de informática ou bancos de dados." A Presidente justificou o veto, afirmando que os dispositivos apresentavam definições "excessivamente amplas e imprecisas." Além disso, concluiu que eram atos com diferentes potenciais ofensivos, mas com penas idênticas, o que viola o princípio da proporcionalidade e da taxatividade. A chefe do Executivo argumentou, também, haver outros incisos que já garantem a previsão das condutas graves que devem ser consideradas atos de terrorismo (PRESIDÊNCIA DA REPÚBLICA, 2016).

O artigo $4^{\circ}$, também vetado pela Presidente da República, dizia respeito à tipificação do crime de apologia ao terrorismo, entendido como "fazer publicamente apologia de ato terrorista ou de autor de ato terrorista." Se não se sabe o que é ato terrorista, qualquer um que possa ter se manifestado a favor de algum grupo ou ação que posteriormente venham a ser considerados terroristas, mesmo que seja uma greve, manifestação ou ocupação, poderia, pelo texto, ser incriminado por isso, sendo considerado terrorista também. Impossível se imaginar todos os efeitos destruidores que isso representaria para a liberdade de expressão, o que por si só já bastaria como argumento para o veto total de tal projeto em um regime dito democrático. 
Aliás, no texto substitutivo do Senador Aloysio Nunes Ferreira (PSDB-SP), aprovado no Senado e enviado para votação na outra Casa, restaram evidenciados os danos e riscos em potencial produzidos pela regulamentação do terrorismo à proteção dos direitos fundamentais no Brasil. $\bigcirc$ substitutivo em questão não apenas suprimiu o parágrafo $2^{\circ}$ do artigo $2^{\circ}$, que exclui da apreciação da nova legislação a "conduta individual ou coletiva de pessoas em manifestações políticas, movimentos sociais, sindicais, religiosos, de classe ou categoria profissional", como também acrescentava a expressão "extremismo político" para a determinação da figura do terrorista (SENADO FEDERAL, 2015). A supressão desse artigo $2^{\circ}, \mathbb{\$} 2^{\circ}$, da ora aprovada Lei 13.260/2016, foi justificada com a simples alegação de que "o país precisa de uma lei precisa, uma regra clara, que garanta segurança jurídica, especialmente em períodos de grandes eventos como as Olimpíadas de 2016." (AGÊNCIA SENADO, 2015).

Prevaleceu, pois, a redação aprovada pela Câmara dos Deputados, remanescendo o dispositivo (artigo $2^{\circ}, \mathbb{S} 2^{\circ}$ ) que busca não aplicar a Lei 13.260/2016 às condutas individuais ou coletivas de pessoas em manifestações políticas, movimentos sociais, sindicais, religiosos, de classe ou de categoria profissional, direcionados por propósitos sociais ou reivindicatórios, visando a contestar, criticar, protestar ou apoiar, com o objetivo de defender direitos, garantias e liberdades constitucionais, sem prejuízo da tipificação penal contida em lei.

No entanto, a Lei 13.260/2016 acaba por alimentar apenas um efeito simbólico que, ao invés de incrementar a sensação de segurança, mostra-se como uma solução fictícia e, o que é pior, pode produzir resultados contraproducentes (CALLEGARI; LINHARES, 2015). Isso porque a Lei 13.260/2013, apesar de todos os vetos operados e da regra contida no artigo $2^{\circ}$, $\$ 2^{\circ}$, se não bem compreendida, pode continuar sendo uma ameaça aos movimentos populares, à luta social por cidadania efetiva e à afirmação dos direitos fundamentais no Brasil. É certo que os vetos minimizaram esses riscos quando suprimiram expressões vagas contidas no artigo $2^{\circ}, \mathbb{\$} 1^{\circ}$, incisos II e III, que tratavam da definição dos atos de terrorismo, quando deixou de criminalizar o tipo penal da apologia ao terrorismo, ou quando impunha aos condenados o regime fechado e o cumprimento da pena em estabelecimento penal de segurança máxima (artigo 9º. Porém, remanesce, por exemplo, a criminalização aos atos preparatórios de terrorismo (artigo $5^{\circ}$ ), o que implica a manutenção de definições excessivamente amplas e imprecisas.

Megaeventos esportivos, como a Copa do Mundo de 2014 e as Olimpíadas de 2016, têm se assentado como instrumentos de colocação de centros urbanos nos novos fluxos financeiros internacionais. Conforme Harvey (2008), esses eventos exigem um projeto urbano de reestruturação das cidades-sedes, o qual confere valor de mercado a áreas antes esquecidas ou descomoditizadas. Pela especulação imobiliária e financeira, o efeito social dos projetos vistos como fundamentais para os novos tempos tem deflagrado um conjunto de violências materiais e simbólicas, como a expulsão da população pobre, a apropriação de áreas públicas, a eliminação do comércio 
local, a utilização de dinheiro público para financiar empreendimentos privados, o apagamento da memória da cidade, entre outros desdobramentos.

A liderança tomada por diversos movimentos sociais e políticos nos protestos contra esses projetos acaba colocando referidas manifestações como o principal, senão o único, elemento de resistência à marcha de comoditização da cidade, que inibe, especialmente da população mais vulnerável, o acesso ao pleno desenvolvimento das funções sociais da cidade, o bem-estar dos cidadãos e o equilíbrio socioambiental. Ademais, a necessidade de cumprir rigorosos padrões de investimentos em áreas esportivas para satisfazer os moldes impostos pela Fédération Internationale de Football Association (FIFA) ou do International Olympic Committee (COI), patrocinados por interesses privados, eleva os custos das obras, retirando dinheiro público de políticas públicas indispensáveis à promoção do mínimo existencial (em saúde, educação, transporte, etc.), com maior impacto à população mais vulnerável.

Sob esse ponto de vista, a Lei 13.260/2016 não pode prejudicar a liberdade fundamental de associação e de manifestação para proteger os novos negócios e investimentos privados nem sempre voltados à promoção dos direitos fundamentais da população mais carente.

Afinal, é possível distinguir, com clareza, os atos terroristas das manifestações sociais, mesmo quando estas tomam proporções violentas (CALLEGARI; LINHARES, 2015). Não obstante os atos terroristas e os movimentos sociais tenham em comum a vontade de promover alterações políticas, essas manifestações estão voltadas ao Estado e não têm como característica o amedrontamento ou o terror, mediante ataques violentos à própria população civil (apesar de, eventualmente e, em geral, por uma minoria de participantes, causarem danos ao próprio Estado, isto é, ao seu patrimônio ou aos agentes que atuam em seu nome). Com efeito, os movimentos sociais estão no exercício de direitos fundamentais que integram a participação política e são inerentes à condição de cidadãos e ao regime democrático (destacando-se, entre outros, os previstos no artigo 5, incs. IV e XVI, da Constituição Federal), voltando-se contra o Estado e sem organização e planejamento de ações de extrema violência.

Por outro lado, a nova Lei surge, entre outros motivos, da necessidade de combater o financiamento ao terrorismo, de modo a cumprir acordos internacionais firmados pelo Brasil, principalmente em relação a organismos como o grupo de Ação Financeira (Financial Action Task Force [FATF], ou GAFI, em francês) (BRASIL, 2015a). Com outros organismos o GAFI integra uma rede de proteção que busca atuar em relação a padrões institucionais que possam produzir efeitos negativos sobre a "integridade" do sistema financeiro (FATF - GAFI, 2012), combatendo as ameaças ocasionadas pela lavagem de dinheiro e pelo financiamento ao terrorismo (BRASIL, 2015a).

Para isso, o GAFI desenvolve uma série de recomendações baseadas em seu julgamento a respeito de vulnerabilidades no âmbito nacional e, em seguida, monitora a aplicação dessas medidas em seus países-membros. Ao final, emite relatórios de avaliação que classificam os países como conformes, parcialmente conformes e não conformes às recomendações (MACHADO; GONÇALVES, 2015). 
Como recompensa pelo cumprimento das recomendações, o órgão declara que aquele país possui um ambiente considerado seguro para os negócios, representando um sinal verde ao mercado financeiro, o que serve para estimular a realização de transações naquele país. Desde janeiro de 2015, havia certa inquietação pelo Ministério da Fazenda quanto ao risco de o Brasil entrar na lista negra do GAFI, por conta da falta de legislação que criminalizasse o financiamento do terrorismo (MACHADO; GONÇALVES, 2015).

Todavia, as recomendações do GAFI, consideradas saudáveis para o sistema financeiro, interferem na proteção da liberdade de associação e manifestação de movimentos sociais. Em fevereiro de 2012, a Transnational Institute e a Statewatch, duas organizações internacionais, após realizarem ampla pesquisa sobre o teor das reformas legais nacionais deflagradas pela Recomendação Especial VIII do GAFI, demonstraram que o sistema de avaliação desse organismo

aprovou alguns dos mais restritivos regimes regulatórios de organizações sem fins lucrativos de todo o mundo e encorajou fortemente governos que já têm caráter repressivo a introduzir novas regras capazes de restringir ainda mais o espaço político de ONGs e atores da sociedade civil. (HAYES, 2012).

A finalidade social do GAFI é proteger a integridade do sistema financeiro (CONSELHO DE CONTROLE DE ATIVIDADES FINANCEIRAS, 2015). Quando tal integridade se associa à promoção de um megaevento esportivo, seus focos de oposição (movimentos políticos e sociais) tornam-se fatores de insegurança para o sistema financeiro e os negócios. Em tal contexto, não é difícil justificar o temor dos cidadãos em serem rotulados como terroristas.

Atenta-se que o GAFI não pertence ao sistema das Nações Unidas, e suas decisões não são de cumprimento obrigatório. Em nota publicada de repúdio ao PLE 2.016/2015, que redundou na aprovação da Lei 13.260/2016, mais de 80 entidades, movimentos e coletivos ligados à luta social no Brasil afirmam que

a lei sobre organizações criminosas - e todos seus instrumentos, tais como colaboração premiada e infiltração - já se aplica às organizações terroristas internacionais, cujos atos de suporte, de preparação ou de execução ocorram ou possam ocorrer em território nacional. (MOVIMENTOS..., 2015).

Egito e Tunísia, dois países que receberam o selo de conforme do GAFI, criaram regras, leis e um aparato de segurança que coíbe de forma abrangente a ação de movimentos sociais orientados à defesa de direitos humanos e das reformas democráticas. A Recomendação VIII se colocou como uma resposta, entre muitos outros instrumentos de reação, à Primavera Árabe e aos processos de mudança das estruturas de poder nessas sociedades. Além disso, em outros 10 países (Camboja, Mianmar, Indonésia, Índia, Colômbia, Paraguai, Serra Leoa, Arábia Saudita, Uzbequistão e Rússia) legislações endossadas pelo GAFI restringiram direitos de organização e manifestação de movimentos sociais (MACHADO; GONÇALVES, 2015). 
No Brasil, onde ações de pressão a protestos populares são marcantes, também é preciso estar atento a possíveis retrocessos na proteção dos direitos fundamentais. Tal contexto é reforçado pela própria natureza do GAFI, cuja "falta de controle democrático, fiscalização e accountability tem permitido regulações que violam os direitos humanos, a proporcionalidade e a efetividade", não se podendo descuidar que essas regulações visam integrar os "padrões da boa governança" do capitalismo financeiro global (HAYES, 2012).

Na construção de um Direito Penal que promova justiça, a lei penal, considerando a intensidade de restrições que pode significar à liberdade individual, demanda moderação e cuidado na sua aplicação. Com a finalidade de proteger o cidadão do arbítrio, de intervenções desnecessárias à sua intimidade e liberdade ou do erro judiciário, criou-se, no âmbito do Estado Democrático de Direito, um sistema de garantias constitucionais e processuais, o qual é ameaçado com legislações rígidas, como a Lei 13.260/2016.

A Lei 13.260/16 precisa ser interpretada e aplicada com bom senso, para que não seja usada para qualificar movimentos sociais como terroristas ou ações de luta social como atos de terrorismo. A lei antiterrorismo brasileira é composta por expressões indeterminadas e maleáveis, capazes de comportar, de acordo com a ideologia e vontade do intérprete, condutas e contextos dos mais diversos possíveis. Não se sabe, por exemplo, o que pode vir a ser caracterizado como "terror social ou generalizado" (artigo 2, caput) ou "destruição em massa" (artigo 2, $\mathbb{S} 1^{\circ}$, inc. I).

Não se pode esquecer que, no Brasil, a sensação de insegurança da população, muitas vezes, serve de justificativa para a aplicação de medidas penais restritivas. Assim, muitos juízes brasileiros se utilizam desse sentimento social para, baseados em percepções subjetivas de expressões vagas como a "ordem pública" do artigo 312 do Código de Processo Penal, decretar prisões preventivas de cidadãos que ainda não foram processados e julgados. ${ }^{3}$

\footnotetext{
3 "HABEAS CORPUS. CRIME DOLOSO CONTRA A VIDA. PRISÃO CAUTELAR. FUNDAMENTAÇÃO IDÔNEA. GARANTIA DA ORDEM PÚBLICA. DELIMITAÇÃO CONSTITUCIONAL DESSE FUNDAMENTO DA PRISÃO PREVENTIVA. ORDEM DENEGADA. 1. Muito já se escreveu sobre esse fundamento específico da prisão preventiva, previsto no art. 312 do CPP. Para alguns estudiosos, serviria ele de instrumento para evitar que o acusado, em liberdade, praticasse novos crimes ou colocasse em risco a vida das pessoas que desejassem colaborar com a Justiça, causando insegurança no meio social. Outros preferem associar a ordem pública à credibilidade do Poder Judiciário e das instituições públicas. Por fim, há também aqueles que encaixam no conceito de ordem pública a gravidade do crime ou a reprovabilidade da conduta, sem falar no proverbial 'clamor público', muitas vezes confundido com a repercussão, na mídia, causada pelo suposto delito. 2. No seu cotidiano exercício de interpretação constitucional do Direito Penal e Processual Penal, o Supremo Tribunal Federal já consolidou o entendimento de que o uso de expressões fortemente retóricas ou emocionais, além do apelo à credibilidade da Justiça ou ao clamor público, não se prestam para preencher o conteúdo da expressão 'ordem pública'. Seja porque não ultrapassam o campo da mera ornamentação linguística, seja porque desbordam da instrumentalidade inerente a toda e qualquer prisão provisória, antecipando, não raras vezes, o juízo sobre a culpa do acusado. 3. Em matéria de prisão cautelar, a expressão 'ordem pública', justamente, é a que me parece de mais difícil formulação conceitual. Como a Constituição fala de 'preservação da ordem pública e da incolumidade das pessoas e do patrimônio', fico a pensar que ordem pública é algo diferente da incolumidade do patrimônio, como é algo diferente da incolumidade das pessoas. É um tertium genus. Um conceito negativo mesmo: ordem pública é bem jurídico distinto da incolumidade das pessoas e do patrimônio. Enquanto a incolumidade das pessoas e do patrimônio alheio vai servir como a própria razão de ser da criminalização das condutas a ela contrárias, a ordem pública é algo também socialmente valioso e por isso juridicamente protegido, mas que não se confunde mesmo com tal incolumidade. Mais que isso: cuida-se de bem jurídico a preservar por efeito, justamente, do modo personalizado ou das especialíssimas circunstâncias subjetivas em que se deu a concreta violação da integridade das pessoas e do patrimônio de outrem, como também da saúde pública. Pelo que ela, ordem pública, se revela como bem jurídico distinto daquela incolumidade em si, mas que pode resultar mais ou menos fragilizado pelo próprio modo ou em função das circunstâncias em que é penalmente violada a esfera
} 
Aliás, a mesma crítica poderia ser feita em relação ao artigo 20 da Lei de Segurança Nacional (Lei 7.170/1983), cujo texto definia o crime de terrorismo nos seguintes termos:

Devastar, saquear, extorquir, roubar, sequestrar, manter em cárcere privado, incendiar, depredar, provocar explosão, praticar atentado pessoal ou atos de terrorismo, por inconformismo político ou para obtenção de fundos destinados à manutenção de organizações políticas clandestinas ou subversivas. Pena - reclusão, de 3 a 10 anos. Parágrafo único. Se do fato resulta lesão corporal grave, a pena aumenta-se até o dobro; se resulta morte, aumenta-se até o triplo. (NERES JÚNIOR et al., 2016).

Entretanto, tal artigo, em razão da interpretação doutrinária, não poderia ser aplicado, justamente pela generalidade de seu preceito primário, isto é, a definição insuficiente da conduta de praticar atos terroristas, o que violava o princípio constitucional da legalidade, sob o aspecto da taxatividade (NUNES JÚNIOR et al., 2016).

De qualquer forma, uma organização terrorista é aquela que pratica atos terroristas - o que, como já salientado, e apesar do esforço do artigo 2 da Lei 13.260/2016, é de difícil conceituação, pois nem todas as condutas que dispersam terror na sociedade devem ser passíveis de tipificação do crime de terrorismo.

Apesar de não haver um consenso sobre um conceito universal de terrorismo, seis elementos básicos podem ser citados para buscar tentar caracterizar penalmente o crime resultante dos atos terroristas (CALLEGARI; LINHARES, 2015):

a) discurso do terror: é necessário um fato específico que tenha por objetivo imediato a difusão do sentimento de terror;

b) aleatoriedade do terrorismo: é da essência do crime a indiscriminação (indeterminação), em razão da alta tendência à letalidade e da amplitude da escala, em relação às vítimas;

\footnotetext{
de integridade das pessoas ou do patrimônio de terceiros. Daí a sua categorização jurídico-positiva, não como descrição de delito ou cominação de pena, mas como pressuposto de prisão cautelar; ou seja, como imperiosa necessidade de acautelar o meio social contra fatores de perturbação que já se localizam na peculiar execução de certos crimes. Não da incomum gravidade desse ou daquele delito, entenda-se. Mas da incomum gravidade da protagonização em si do crime e de suas circunstâncias. 4. Não há como desenlaçar a necessidade de preservação da ordem pública e o acautelamento do meio social. No mesmo passo em que o conceito de ordem pública se desvincula do conceito de incolumidade das pessoas e do patrimônio alheio, ele se liga umbilicalmente ao conceito de acautelamento do meio social. Acautelamento que não se confunde com a mera satisfação de um sentimento generalizado de insegurança, senão com medidas de efetiva proteção de uma certa comunidade; ou seja, se a ambiência fática permite ao magistrado aferir que a liberdade de determinado indivíduo implicará a insegurança objetiva de outras pessoas, com sérios reflexos no seio da própria comunidade, abre-se espaço para o manejo da prisão em prol da ordem pública. Insegurança objetiva, portanto, que direciona o juízo do magistrado para a concretude da realidade que o cerca. Não para um retórico ou especulativo apelo à indeterminação semântica daquilo que tradicionalmente se entende por 'paz pública'. 5. No caso, a custódia preventiva do paciente não foi decretada tão-somente em meras suposições de risco à garantia da ordem pública, ou na gravidade em abstrato do crime debitado ao paciente. Trata-se de decisão que indicou objetivamente dados concretos quanto à premente necessidade de acautelamento do meio social, notadamente quanto ao modus operandi brutalmente incomum. Deveras, quando da maneira de execução do delito sobressair a extrema periculosidade do agente, o decreto de prisão ganha a possibilidade de estabelecer um vínculo funcional entre o modus operandi do suposto crime e a garantia da ordem pública. Isso na linha de que a liberdade do paciente implicará a insegurança objetiva de outras pessoas, com sérios reflexos no seio da própria comunidade. 6. Ordem denegada." (HC 111244, Relator(a): Min. AYRES BRITTO, Segunda Turma, julgado em 10/04/2012, PROCESSO ELETRÔNICO DJe-124 DIVULG 25-06-2012 PUBLIC 26-06-2012).
} 
c) instrumentalização das vítimas: as vítimas do ato de violência são meros instrumentos necessários para a disseminação do terror (mensagem terrorista);

d) possibilidade de reiteração de atos: o que amplifica o medo do terrorismo é a possibilidade do mesmo ato já consumado se repetir a qualquer momento;

e) qualidade organizacional: é necessária uma organização estratégica prévia, dem decorrência da sua complexidade, própria de uma estrutura coletiva;

f) finalidade política: o objetivo último ou a especial motivação do crime é causar uma modificação política, sendo o ato terrorista dirigido, preponderantemente, ao Estado, não às pessoas atingidas pela violência.

A Lei brasileira, no seu artigo $3^{\circ}$, acrescenta que aquele que faz parte (isto é, promove, constitui, integra ou presta auxílio, pessoalmente ou por interposta pessoa) de tal organização terrorista fica sujeito à reclusão de cinco a oito anos e à multa. Da mesma forma, pelo artigo $6^{\circ}$, quem recebe, provê, oferece, obtém, guarda, mantém em depósito, solicita, investe, de qualquer modo, direta ou indiretamente, recursos, ativos, bens, direitos, valores ou serviços de qualquer natureza para o planejamento, a preparação ou a execução dos crimes previstos na Lei 13.260/2016 está sujeito a uma pena de 15 a 30 anos de reclusão. Enfim, a Lei brasileira antiterror, em sua maior parte, criminaliza ações que se supõe abstratas e eventualmente estarem ligadas a um possível ato terrorista, e que não exigem dano efetivo para se configurar. Prevê, ainda, a criminalização de condutas preparatórias (artigo 5), dispensando qualquer resultado ou risco de um resultado lesivo.

Em parecer técnico elaborado pela Associação Juízes para a Democracia (2015), alerta-se que o princípio da estrita legalidade exige que a conduta criminalizada seja perfeita e objetivamente delimitada por lei anterior, em ordem a permitir que se conheça, de antemão, os limites do comportamento penalizado, evitando, com isso, a proliferação de tipos penais com conceitos demasiadamente abertos e indeterminados. Ademais, na contramão das garantias democráticas, surge o projeto antiterror, abarcando penas elevadíssimas e tipos penais de conceitos equivocados, como obter "ativo, bem ou recurso financeiro com a finalidade de financiar [...] prática de terrorismo." De acordo com a associação, tais condutas são verdadeiros "coringas performáticos colocados a serviço do patrulhamento ideológico e da expansão do Estado policial." (ASSOCIAÇÃO JUÍZES PARA A DEMOCRACIA, 2015). Em outro parecer técnico da Rede Justiça Criminal (2015), o projeto é taxativo, entendendo que a Lei "não protege nenhum novo bem jurídico e expõe os cidadãos brasileiros à censura penal de atos políticos."

Diante da utilização de expressões indeterminadas e abertas, é inegável que a lei brasileira antiterrorismo permite arbitrariedades e retrocessos na proteção dos direitos fundamentais. $\bigcirc$ principal risco da nova lei se encontra na crença de que sua aplicação vai atingir apenas o terrorista e não os cidadãos de bem, embora tal separação não seja sempre fácil e clara. Na fluidez do mundo 
contemporâneo, não é difícil inserir tal rótulo em qualquer pessoa, ainda que a real motivação seja a supressão de direitos fundamentais.

Os movimentos sociais, mesmo que por vezes exista a presença de pessoas infiltradas que pratiquem vandalismo ou violência (como os black blocks), não expõem a nenhum risco as instituições democráticas, sendo indispensáveis à consolidação e avanço dos direitos fundamentais, à promoção da cidadania, ao combate à corrupção, aos privilégios indevidos e às injustiças sociais, bem como ao desenvolvimento ético do País. Condutas, como as praticadas por black blocks, quando configurarem crimes comuns, têm sua resposta em nosso ordenamento jurídico, não exigindo a incidência de leis antiterror, uma vez que, nos termos da Convenção Interamericana contra o Terrorismo, ratificada pelo Brasil em 2005, "o terrorismo constitui uma grave ameaça para os valores democráticos e para a paz e a segurança internacionais."

O Brasil é um país pacífico e sem histórico de atos de terrorismo que justifiquem a importação de modelos estrangeiros, seja na tentativa de fabricação de uma onda terrorista totalmente inexistente em nosso território, seja para promover retrocessos na proteção de direitos fundamentais ou inibir a participação popular em movimentos legítimos de solidificação do Estado Democrático de Direito.

A preocupação com a criminalização do terrorismo e a inserção do Brasil no contexto global não pode ser transformada em uma histeria coletiva, a justificar o endurecimento do controle social - que, infelizmente, atinge de forma mais contundente as camadas mais vulneráveis da população - e que acaba por beneficiar outros setores da sociedade, que lucram com a suposição de novas situações de risco, com o objetivo de ampliarem a venda de armamentos ou de outros meios de defesa, mas também contribuem para a manutenção da hegemonia mundial política, econômica e bélica.

Portanto, a Lei 13.260/16, ao se colocar em sintonia com os interesses econômicos globais, precisa ser aplicada com cautela, para não se transformar em uma ferramenta eficaz para inibir protestos contra o status quo, o sistema e a crescente onda política conservadora, já que isso comprometeria a participação popular indispensável ao aprimoramento do Estado Democrático de Direito no Brasil.

\section{Globalização e terror}

A fim de mediar aspectos econômicos e psíquicos, o fator político deve ser uma espécie de ponte. $O$ termo terror, ainda que não em sua acepção primeira, também remete a uma forma de governar: a que Robespierre fez durante a Revolução Francesa e que depois passou, como triste herança, para muitos outros regimes autoritários. 
método de luta do terrorismo transterritorial ocorre nos fluxos da sociedade de controle, atravessando os mesmos trânsitos computo-informacionais nos quais se movimentam empresas, governos e ONGs.

O combate ao terrorismo é fluído, difundindo-se pelo Planeta e lançando mão de tecnologias de rastreamento sideral e eletrônico, prisões discricionárias, torturas e assassinatos, monitoramento das condutas, invasões de privacidade e ocupações militares articuladas por coalisões de democracias liberais.

Os combates ao terror e à jihad formam um duplo complementar no Planeta, em uma guerra sem espacialidade, combatentes, jurisdição e temporalidade, definidos naquilo que Gros (2009) denomina de estados de violência. Esses estados de violência atravessam fronteira e incidem sobre a vida de cada um em tempos de suspeição geral: das múltiplas vigilâncias cotidianas aos variados estados de exceção, justificando-se, em nome da segurança das populações, dos Estados, da democracia e do Planeta.

Não é mais apenas a guerra da razão de Estados, voltada à balança do poder do sistema internacional que despontou no final da Idade Média (FOUCAULT, 2008b). O dispositivo de segurança da sociedade disciplinar, combinando biopolíticas das populações com o equilíbrio diplomático-militar entre os Estados, passa por transformações que anunciam a emergência de um novo dispositivo de segurança planetária ainda em plena confirmação (RODRIGUES, 2012).

Nessa nova era em que vivemos, não se governa somente a população (PASSETTI, 2011, p. 133). Há um novo alvo de proteção: o Planeta e a vida dentro e fora dele. Emerge uma ecopolítica de controle do meio ambiente, com sustentabilidade combinada com a biopolítica herdada da sociedade disciplinar. Dessa forma, redimensionaram-se as centralidades e redefine-se a soberania política, surgindo novos arranjos institucionais como a União Europeia, que ensaiam uma concentração de poder político para além do Estado-nação; missões multilaterais e multidimensionais substituem as antigas missões de paz da ONU por novas operações combinadas entre exércitos; ONGs e empresas se interessam pela construção de Estados à imagem e semelhança do Estado democrático-liberal em países considerados Estados falidos; muitas das oposições lançadas contra esse Estado democrático-liberal recorrem à demanda por direitos - que as faz voltar ao Estado - ou evocam outra universalidade política centralizadora, como a jihad islâmica.

Se o terrorismo "é uma presença inevitável enquanto houver Estado" (PASSETTI, 2006, p. 107), o redimensionamento do poder político em novas institucionalidades na sociedade de controle propicia novos terrorismos. Em nome da democracia ou de Alá, os terrorismos contemporâneos se amalgamam. Há mais de 100 anos, o terrorismo anarquista abalou a referência que unia os terrorismos de então ao Estado revolucionário ou ao Estado Nacional. Porém, é necessário questionar: haverá na sociedade de controle centelhas resistentes e combativas que se coloquem contra as novas centralidades redimensionadas do poder político? 
De qualquer modo, é certo que o terrorismo tem alterado o mapa geopolítico do Planeta. Basta considerar que atos considerados terroristas desencadearam intervenções em uma série de países, como no Afeganistão, e mais ainda, guerras como a do Iraque. É como se os governos, principalmente os ocidentais, tivessem desenvolvido uma hipersensibilidade às questões de segurança, que é transmitida às suas respectivas opiniões públicas.

Deve ser destacado o caráter sintomático dessa situação. Não há dúvidas que as metrópoles da globalização se inserem nas sociedades mais seguras da história da humanidade. Sanfélix-Vidarte (2013, p. 89-90) se refere à intolerância à insegurança, apontando como causa dessa "hiperfobia" os altos níveis de segurança atingidos no seio de nossas sociedades. Tal fenômeno é alimentado por outros fatores não menos característicos da época global, como a onipresença dos meios de comunicação de massa, cuja atuação baseada no sensacionalismo se transforma em uma estratégia adaptativa às demandas do mercado para que a informação passe a ser rentável, proporcionando lucros ou ganhos políticos.

Safranski (2005, p. 84), ao buscar responder à pergunta de quanta globalização podemos suportar, afirma explicitamente que o terrorismo age em dois planos: o concreto e o simbólico. De um lado estão as ações, mas, ao mesmo tempo, é igualmente importante a difusão da notícia dos horrores. Por isso, a mídia se transforma em cúmplice involuntária do terrorismo, pois os terroristas produzem o horror com a esperança de que os outros o difundam. A essência do terrorismo moderno implica, pois, o uso do aparato da mídia com sua forma específica de difundir mensagens e ampliar o alcance das ações violentas.

Na sociedade global, o sentimento de medo se amplifica pelos meios de comunicação e, com seus múltiplos ecos, agiganta-se de modo sistemático. O combate ao crime, na forma explorada por produtores e redatores dos meios de comunicação, apresenta um excelente e excitante espetáculo, incomparavelmente mais extraordinário que qualquer ação voltada para as causas da violência (BAUMAN, 1999, p. 126).

A desproporção entre o pânico gerado e a periculosidade objetiva do fenômeno que o desencadeia, junto com o benefício que alguns setores econômicos e políticos tiram dessa situação, torna difícil resistir contra o conselho popperiano de fugir das teorias conspirativas da história de que podem existir alguns interesses sórdidos fomentando o crescimento do medo (SANFÉLIX-VIDARTE, 2013, p. 91).

As representações dramáticas do terrorismo pelos meios de comunicação de massa geram efeitos nocivos sobre a carga emocional que acompanha a percepção de certos fenômenos por parte dos cidadãos do mundo globalizado. O desajuste entre o medo experimentado causado por certos eventos e sua periculosidade objetiva acaba condicionando a própria forma de percepção dos fenômenos.

O efeito geral da repetição diária de dramas, baseados em histórias reais ou misturados à ficção, é a autopropulsão do medo: a preocu pação com a segurança pessoal, sobrecarregada de sen- 
tidos para além da sua capacidade em virtude da insegurança e incertezas psicológicas, aumenta as ansiedades humanas e a popularidade de governos que criminalizam mais condutas, elevam as penas, constroem presídios, etc., tudo para dar a sensação de "fazerem algo" pela segurança individual dos governados (BAUMAN, 1999, p. 127).

A evolução tecnológica, ao diminuir o intervalo entre um ato violento e o momento que dele se toma conhecimento, contribui para a espetacularização da violência, a ponto de se poder assistir ao vivo eventos como a queda das Torres Gêmeas em Nova Iorque ou os atentados terroristas em Paris em 2015. O presente é agora amplo como nunca antes o foi, porque no agora somos capazes de presenciar, como em nenhum momento da evolução humana, eventos que não acontecem em nossa presença física. E se o presente se torna mais complexo, ele também se projeta no futuro ou decai no passado - daí a sensação de que o tempo está voando ou de que esquecemos os fatos com muito mais facilidade.

\section{Terrorismo de estado: o verdadeiro inimigo}

Dentro do espectro mais amplo dos crimes de Estado é que se torna mais palpável o fenômeno conhecido como terrorismo de Estado. À medida que parte da população civil é selecionada como alvo das ações repressivas do Estado, uma série de políticas são colocadas em ação, e boa parte delas inclui ações violentas e ilegais que se amoldam na categorização de atos terroristas, como sequestros, desaparecimentos, tortura, atentados a bomba, assassinatos, estupros e constantes invasões de domicílio. Para que tais condutas possam retratar o terrorismo de Estado, elas devem ser percebidas em um contexto de política delinquente, na prática massiva de tais ações pelos próprios agentes políticos ou de grupos por eles apoiados, sustentados nas diretrizes políticas fornecidas pelo governo.

Salienta-se que para a existência do terrorismo de Estado não é condição indispensável o funcionamento de um governo autoritário ou de uma ditadura; porém, nestes casos, percebe-se que a repressão se alarga com o tempo, atingindo um espectro cada vez mais amplo da população, com uma clara militarização das relações sociais, em que todos são suspeitos. Além de trabalhar para a invisibilização dos crimes cometidos, especialmente quanto ao terror por eles desencadeado, o Estado projeta o vocativo de terrorista para os grupos que são alvos de sua perseguição.

Por possuir o monopólio da violência, o Estado é o ente que tem as maiores probabilidades de usá-la de forma imprópria, ocasionando consequências funestas. A serviço do Estado estão aparelhos repressivos fortemente treinados e armados. Na estruturação de tais instituições, há uma organização burocrática complexa e dotada de inúmeras ramificações, com um conjunto ideológico que justifica suas ações, além de forte sentimento corporativo e racionalidade instrumental que ultrapassam todas as suas instâncias. Nenhuma organização criminosa, por mais evo- 
luída que seja, conseguiria igualar tal poderio, a não ser que começasse a tomar contornos de um proto-Estado, prestes a dar um golpe ou concretizar uma revolução (GREEN; WARD, 2009, p. 3).

A percepção atual das organizações dissidentes, sejam elas domésticas sejam internacionais, como problema penal, sobretudo aquelas cuja atuação é estruturada na utilização de métodos terroristas, tem levado à construção de um novo discurso defensivista. Fundado em premissas análogas àquelas nas quais objetiva intervir, a resposta punitiva para o combate dos grupos terroristas é moldada a partir de um congênere direito penal do terror, sintetizado na ideia de que "contra o terror das organizações criminosas o terrorismo de Estado." (CARVALHO, 2006, p. 256).

Com isso, é possível verificar o redimensionamento do marco ideológico defensivista, o qual assume formalmente a dicotomia bem e mal, com estruturação explícita da beligerância como norte programático do direito e do processo penal. $O$ direito penal do inimigo trabalha com a categoria de unpersonen (não pessoas), em uma lógica de guerra contra os terroristas, os mafiosos e os excluídos sociais, que comporiam uma classe de indivíduos não confiáveis e, com isso, não seriam considerados pessoas (NUNES, 2016). O sinal característico do inimigo seria a habitualidade e a profissionalização no cometimento de crimes.

Com efeito, Jakobs (2003, p. 38) não restringe a nova programação apenas aos sujeitos vinculados aos "grupos terroristas", mas a todos aqueles indivíduos cujas atitudes, por meio de incorporação e organização criminosa ou não, demonstrem a possibilidade de reiteração delitiva (periculosidade).

A inevitável ampliação do conceito de inimigo, ao ultrapassar o marco dos integrantes de grupos terroristas para agregar as demais organizações criminosas organizadas, dá condições de expansão do arquipélago de punitividade com a ruptura radical dos sistemas de garantias. A beligerância do discurso penal do inimigo perpassa as atitudes de desrespeito aos direitos exercidas pelas agências repressivas (ilegalidades toleradas), no plano fático, ao discurso legitimador, abrindo espaços para a justificação do terrorismo de Estado.

Quando se detalham os crimes contra a humanidade, pode-se identificar a constância de três elementos que os caracterizam: o caráter inumano e hediondo do ato criminoso; a enunciação não taxativa da enumeração desses atos; e o fato de que sejam praticados em meio a uma política de perseguição geral e sistemática a uma parcela da população civil (INTERNATIONAL CENTER FOR TRANSITIONAL JUSTICE, 2009).

Infelizmente, os três aspectos têm se apresentado de forma crescente nas ações executadas pelos governos nacionais contra a própria população. Esses crimes são chamados de contra a humanidade, pois indicam a completa eliminação de uma parcela inerente à diversidade humana, avançando contra a base que permite a própria existência da política: a pluralidade humana (SILVA FILHO, 2011, p. 11331). É uma situação contraditória, pois o Estado que deveria proteger seus cidadãos em seus direitos fundamentais é aquele que se revela como o principal agente de crimes contra a humanidade. 
Para Bernard (2006), os governos têm todo o interesse em manter o fenômeno do terrorismo delimitado às dimensões não estatais, lançando um véu de obscuridade sobre o terrorismo praticado por si e, em não raras vezes, procurar justificá-lo a partir da existência do terrorismo não estatal. Trata-se, sob a perspectiva dos governos, "de agir para que o terrorismo de Estado não exista aos olhos do cidadão e da comunidade internacional, ou pelo menos, que ele não seja percebido senão como resposta legítima e fundada para um terrorismo prévio, que seria único, autêntico." (BERNARD, 2006, p. 16).

No instante em que o Estado alega defender a democracia fazendo uso de estratégias terroristas, mesmo nas democracias formais, ele não está combatendo ou diminuindo o terrorismo, mas o está elevando a uma categoria muito mais ampla e letal: a do terrorismo de Estado, fenômeno mais nítido, sem dúvida alguma, nos regimes claramente ditatoriais ou totalitários.

Conforme Zaffaroni (2006), a temática dos crimes de Estado é o grande desafio da criminologia para o século XXI. O jurista argentino considera que seria depreciável um saber criminológico que ignore o mais grave de todos os crimes, sendo a omissão um sinal de indiferença e aceitação. Uma interessante razão que conduz a invisibilidade de crimes do Estado mora na própria complexidade na qual eles se cercam. Esses crimes não se limitam ao contexto social e individual do agente simplesmente, mas alcançam a própria estrutura organizacional do Estado (aspectos históricos, políticos, econômicos e culturais). Tendo como exemplo os crimes de Estado cometidos em nome da segurança, percebe-se uma cultura que fornece toda uma justificativa para descaracterizar como criminosas algumas de suas ações. Ao contrário dos crimes comuns, em que se busca uma excludente que o justifique ou desculpe, nos crimes do Estado, o agente que comete um crime apoiado pela própria organização estatal se vê, muitas vezes, como uma espécie de arauto dos valores sociais, reforçados com seu ato.

Por exemplo, nas ditaduras na América Latina dos anos 1960 e 1970, torturar, assassinar, desaparecer com os restos mortais, banir, exilar, caçar, demitir, monitorar, censurar os meios de comunicação e difamar pessoas que eram tidas como subversivas, ou pior, comunistas, eram condutas executadas pelo Estado e justificadas como uma espécie de guerra santa contra o comunismo internacional e a ameaça aos valores cristãos e familiares. Teorias como a Doutrina da Segurança Nacional foram detalhadamente elaboradas e repassadas em cursos, preleções, legislações e publicações.

Em Estados democráticos, da mesma forma, consegue-se perceber a tentativa de legitimação da tortura, seja pelo próprio Direito, seja por intermédio de discursos apologéticos da violência do Estado contra criminosos comuns, sempre baseada em teorias pseudocientíficas, como a de tolerância zero. A dificuldade em se tratar dos crimes praticados pelo Estado é muito maior no âmbito interno de determinado país, pois muitos dos envolvidos com os delitos, de forma direta ou indireta, estão no poder político. Diante desse fato, ganham importância os organismos internacionais de proteção dos direitos humanos. 
No Brasil, a ausência de políticas transicionais mais expressivas mascara uma estrutura fortemente repressiva e militarizada das forças policiais, bem como dos crimes contra a humanidade cometidos pelo Governo Ditatorial. Baseado em tal fato é que se reflete a continuidade do rótulo de terroristas aos grupos que ousaram pegar em armas e exercer o direito de resistência diante da tirania no período do Governo Militar. O que preocupa, no entanto, é não perceber a clara relação entre a estrutura repressiva da ditadura brasileira e a continuidade das mesmas práticas, as quais, agora, não mais focam os subversivos, mas, sim, os criminosos, extraídos em sua grande maioria das camadas mais empobrecidas da sociedade.

Com a redemocratização do Brasil nos anos 1980, o número de esquadrões da morte aumentou, e manteve-se intacta entre as forças de segurança a mesma cultura organizacional formatada no período ditatorial. Continuaram-se as ações violentas, a difusão de responsabilidades e a desumanização dos suspeitos e das vítimas. Na formação policial, realizam-se treinamentos em unidades especiais que, aliados à garantia do anonimato e à absoluta divisão entre a vida profissional e a vida pessoal e social, também desumanizam os agentes públicos, situação agravada pelo culto à obediência hierárquica cega. Inevitavelmente, essas características geram, como efeito, o "descomprometimento moral" dos agentes de segurança envolvidos na prática de atrocidades, disfarçadas como mera prática profissional (HUGGINS; HARITOS-FATOUROS; ZIMBARDO, 2006).

Tais estratégias durante a Ditadura serviram em larga escala para sustentar a Doutrina da Segurança Nacional e identificar um inimigo interno a ser combatido, lógica essa que continua existindo nas corporações policiais. As forças policiais brasileiras possuem ampla autonomia para definir o que é ou não excesso de violência, sendo blindadas a qualquer tipo de controle democrático pela sociedade, dada a sua natureza refratária e a pouquíssima reformulação institucional após a redemocratização do País (HUGGINS; HARITOS-FATOUROS; ZIMBARDO, 2006, p. 426).

Verifica-se, pois, o quanto a prática de terrorismo de Estado no Brasil e a ausência de reconhecimento desse fato no espaço público, além das precárias medidas transicionais, ajudaram fortemente no atingimento dos elevados níveis de violência das forças de segurança no País, e o quanto no presente se continua a pagar o preço pelo adotado nos anos de chumbo. Exemplo disso são os números de mortes por ação policial no Brasil: em São Paulo, foram registrados, em 2014, 32 homicídios de civis para cada homicídio de policial, enquanto nos Estados Unidos a média é de um homicídio de policial para cada 12 homicídios de civis.

Extrai-se que o Estado, quando define grupos com potencialidade delitiva, reinstitui dimensões de periculosidade características da criminologia etiológico-positivista, destituindo dos seus membros o status de pessoa, e acaba por renunciar a própria noção de Estado Democrático de Direito (CARVALHO, 2006, p. 259). Apenas nos projetos políticos totalitários (Estados de exceção) a ideia que faz da segurança pública seu referencial se ergue sobre a dignidade da pessoa humana. Tal destituição da cidadania inevitavelmente transforma o sujeito (de direitos) em mero objeto de intervenção policial. 
Se na América Latina o discurso de emergência sempre foi revigorado pelas agências repressivas como instrumento de legitimação das políticas criminais, como a de guerra às drogas, encontrando no "crime organizado" o inimigo visível a se combater, nos dias de hoje, a exceção ganha contornos de Estado de permanência, com a adição do ingrediente do discurso de luta contra o terrorismo. Por operar sob a aparência de respeito às regras dos Estados de direito, mas atuando na verdade em um vácuo de direitos, o efeito do poder punitivo é o de gradual desestabilização das Constituições (CARVALHO, 2006, p. 260).

No momento em que reconstrói a política do século passado e avalia as medidas atuais contra o terrorismo, Agamben (2004, p. 13) verifica a tendência na política contemporânea em apresentar o Estado de exceção como paradigma de governo, executando medidas provisórias e excepcionais como técnicas de administração pública. Acredita-se que a criação de um Estado de emergência permanente, mesmo que não declarado no sentido técnico, tornou-se uma das práticas essenciais dos Estados contemporâneos, inclusive dos chamados democráticos.

$\mathrm{Na}$ constante tensão entre a crise de segurança individual experimentada pela sociedade, que se vê cada vez mais como uma vítima em potencial, e a crise da segurança pública traduzida na incapacidade do Estado de administrar minimamente os riscos, tentações autoritárias brotam com a aparência de eficiência instrumental ao restabelecimento da lei e da ordem. Quando colocados na balança os custos e benefícios, o sacrifício de certos direitos e garantias fundamentais aparenta ter um preço razoável a ser pago pela retomada da segurança. Sua assimilação se faz ainda mais fácil se esses direitos e garantias a serem suprimidos integrarem o patrimônio jurídico de uma pessoa enquadrada na categoria inimigo, considerado como obstáculo ou ameaça que deve ser reputado como ninguém (não ser).

\section{Conclusões}

As alternâncias do conceito de terrorismo se referem a fenômenos tão distintos quanto o exercício do poder, seja pelo medo difundido, pelo grau da violência praticada, seja pela mobilização política, e evidenciam a sua fraqueza como um instrumento político e seu potencial como ferramenta de reivindicação. Terrorismo não é um termo neutro, capaz de identificar e descrever um fenômeno que lhe é exterior. De fato, o uso do conceito faz emergir juízos de valor. Justamente em razão disso é necessário que se faça sua contextualização tanto em face de condições objetivas quanto em relação à percepção que os atores possuem do contexto em que a ação ocorre e de seu significado.

A definição de terrorista é um ato político, não havendo ontologia do terrorista ou do terrorismo. Reparar nisso, ainda que por uma breve sugestão genealógica, pode ajudar na compreensão de que não há segurança do Estado que prescinda desses atos classificados pelo oponente como terroristas. Assim, enquanto houver poderes centralizados e guerra para defendê-los, haverá terrorismos para ampará-los e combatê-los, visando às outras centralidades. $\bigcirc$ atual desenvolvimento de 
sistemas repressivos no obscuro intervalo entre democracia e autoritarismo parece explicar a aproximação entre o direito penal do inimigo e a ideia do Estado de exceção permanente. Tal hipótese ganha relevo ainda maior se atrelada à volatilidade de conceitos como grupos terroristas e terrorismo.

Para se fazer frente ao terrorismo de Estado e o não estatal também e prevenir seu ressurgimento, é indispensável que se compreendam e se identifiquem as conexões práticas, teóricas e políticas que permitem e favorecem a sua existência e desenvolvimento. Na concepção brasileira, é fundamental que o combate ao terrorismo se oriente na nossa própria norma constitucional e de acordo com a Declaração Universal dos Direitos Humanos, a Convenção Interamericana contra o Terrorismo, a Carta da Organização dos Estados Americanos e as demais Normas do Direito Internacional. O repúdio ao terrorismo é, ao lado do racismo, um princípio constitucional que rege nossas relações internacionais e que está previsto no artigo $3^{\circ}$, inciso IV, da Constituição, ao declarar, como um dos objetivos fundamentais da República Federativa do Brasil, a promoção do bem de todos, sem preconceitos de origem, raça, sexo, cor, idade e quaisquer outras formas de discriminação.

O terrorismo é fruto de projetos sociais que minimizam a esfera política ao máximo, deixando em seu lugar a imposição de modelos econômicos e sociais excludentes. A ideia de globalização traz a padronização das diferenças e da pluralidade humana ao impor o modelo liberal de sociedade como neutro e universal. Dos atritos e incongruências gerados no choque das diversidades com os modelos hegemônicos, aparece com vigor o apelo à violência e o recrudescimento do direito penal. Assim, alguns grupos sociais contrários aos modelos hegemônicos quanto os próprios Estados se apegam a uma escalada da força, diante do vácuo do exercício da política.

Confunde-se violência com terrorismo (por má-fé ou ignorância), e a mera repressão não ajuda a melhorar essa realidade de crescimento da brutalidade. A maneira mais efetiva de combater o terrorismo, especialmente o de Estado, é a participação política efetiva tanto na seara nacional quanto na internacional, repudiando-se a violação dos direitos humanos e a prática de políticas delinquentes e de estruturas repressivas autoritárias que impedem o desenvolvimento dos regimes democráticos.

Certamente não se diminui a violência, tampouco se obtém segurança, individual ou coletivamente, com uma guerra contra o terror, que acaba por estimular a criação de um direito penal de exceção, com sacrifício de direitos e garantias fundamentais, como a criminalização de atos preparatórios e a legitimação de formas de tortura. Ao contrário, tais soluções somente fazem aumentar a violência e a sensação de insegurança.

O terrorismo tem servido como desculpa ao enfraquecimento democrático e a constante relativização dos limites à repressão das agências a serviço do Estado. O combate ao terror tem sido uma eficiente estratégia de neutralização para fomentar a prática e o aumento de crimes cometidos pelo Estado. Contraditoriamente, tem-se usado o combate ao terror como uma escusa ao exercício do terrorismo de Estado para com determinados setores da população, especialmente os mais vulneráveis, que é feita de vítima sob a lógica do inimigo interno. 
Cabe aos Estados e organismos internacionais a promoção das políticas transicionais adequadas e a realização de reformas institucionais em seus órgãos de segurança e justiça. Também compete à sociedade civil o estímulo permanente ao exercício da cidadania, pela sua organização, mobilização e participação política efetivas, seja nos espaços institucionais, seja em todos os outros espaços públicos existentes.

No caso brasileiro, ainda se tem muito a trilhar até que ocorra totalmente o rompimento com seu passado autoritário e violento, a fim de se tomar uma direção segura para a construção da democracia, na qual o respeito e a promoção aos direitos humanos fundamentais sejam levados a sério. O Brasil, para promover segurança, precisa mais de políticas públicas eficientes para a promoção de direitos fundamentais que de uma lei antiterror. Afinal, não há histórico de ações ou ameaças terroristas a não ser aquelas praticadas pelo próprio Estado, como o terrorismo das polícias militares contra a população jovem e negra nas periferias das grandes cidades.

O que realmente há de novo na Lei antiterror brasileira, não obstante a regra contida no artigo $2^{\circ}$, $\mathbb{S} 2^{\circ}$, da Lei 13.260/2016, é a margem e o peso que o Estado atribui para o aumento da criminalização de manifestantes e movimentos sociais. Nesse sentido, tal Lei precisa ser interpretada e aplicada com muita cautela, porque, ao possuir um elevado cunho político repressivo, pode trazer retrocessos à democracia participativa. Assim, a liberdade de pensamento e de manifestação pode ser estimulada, bem como a cultura da não violência incentivada, trazendo às ruas novos atores sociais para serem protagonistas das reformas que o País tanto precisa, sem prejuízo da aplicação do direito penal comum àqueles que usam da violência para protestar.

\section{Referências}

AGAMBEN, Giorgio. Estado de Exceção. São Paulo: Boitempo, 2004.

AGÊNCIA SENADO. Aloysio Nunes diz que lei antiterrorismo terá regras claras e não punirá movimentos sociais. 20 out. 2015. Disponível em: <http://www12.senado.leg.br/noticias/materias/2015/10/20/ aloysio-nunes-diz-que-lei-antiterrorismo-tera-regras-claras-e-nao-punira-movimentos-sociais $>$. Acesso em: 15 jan. 2016.

ANISTIA INTERNACIONAL. Statement by Amnesty International on the implementation of Security Council Resolution 1373. 01 Oct. 2001. Disponível em: <https://www.amnesty.org/en/documents/ ior52/002/2001/en/> . Acesso em: 23 fev. 2016.

ASSOCIAÇÃO JUÍZES PARA A DEMOCRACIA. Nota técnica contra a Lei Antiterrorismo. 08 ago. 2015. Disponível em: <http://ajd.org.br/documentos_ver.php?idConteudo=181>. Acesso em: 20 jan. 2016.

AZEVEDO, Tupinambá Pinto; TONETTO, Fernanda Figueira. Justiça penal internacional: do relativismo ao universalismo de valores? Revista Brasileira de Ciências Criminais, v. 120, maio/jun. 2016.

BAUMAN, Zygmunt. Globalização: as consequências humanas. São Paulo: Zahar, 1999. 
BERNARD, François de. A fábrica do terrorismo - um livro incorreto para o uso de grandes pessoas. Tradução Antonio Sidekum. São Leopoldo: Nova Harmonia, 2006.

BOBBIO, Norberto; MATTEUCCI, Nicola; PASQUINO, Gianfranco. Dicionário de política. 11. ed. Brasília, DF: Ed. UnB, 1998. v. 2.

BONANATE, Luigi. Terrorismo político. Verbete do Dicionário de Política. In: BOBBIO, Norberto; MATTEUCCI, Nicola; PASQUINO, Gianfranco (Org.). Brasília, DF: Ed. UnB, 2007.

BRASIL. Lei 13.260, de 16 de março de 2016. Regulamenta o disposto no inciso XLIII do art. $5^{\circ}$ da Constituição Federal, disciplinando o terrorismo, tratando de disposições investigatórias e processuais e reformulando o conceito de organização terrorista; e altera as Leis $n^{\circ}$ 7.960, de 21 de dezembro de 1989, e 12.850, de 2 de agosto de 2013. Diário Oficial da União, Brasília, DF, 17 mar. 2016. Disponível em: <http://www.planalto.gov.br/ccivil_03/_Ato2015-2018/2016/Lei/L13260. htm>. Acesso em: 05 mar. 2016.

BRASIL. Projeto de Lei 2016/2015. Altera a Lei n 12.850, de 02 de agosto de 2013, e a Lei n 10.446, de 08 de maio de 2002, para dispor sobre organizações terroristas. Brasília, DF, 16 jun. 2015a. Disponível em: <http://www.camara.gov.br/proposicoesWeb/prop_mostrarintegra?codteor $=1350712 \&$ filename $=P L+2016 / 2015>$. Acesso em: 15 jan. 2016.

BRASIL. Secretaria Especial dos Direitos Humanos. Comissão Especial sobre Mortos e Desaparecidos Políticos. Direito à verdade e à memória. Brasília, DF: Secretaria Especial dos Direitos Humanos, 2007.

BRASIL. Senado Federal. Projeto de Lei da Câmara n. 101. Regulamenta o disposto no inciso XLIII do art. $5^{\circ}$ da Constituição Federal, disciplinando o terrorismo, tratando de disposições investigatórias e processuais e reformulando o conceito de organização terrorista; e altera as Leis $n^{\circ}$ s 7.960, de 21 de dezembro de 1989, e 12.850, de 02 de agosto de 2013. 20 ago. 2015b. Disponível em: <https:// www25.senado.leg.br/web/atividade/materias/-/materia/122772>. Acesso em: 15 jan. 2016.

CALLEGARI, André Luís; LINHARES, Raul Marques. Terrorismo: uma aproximação conceitual. Revista Brasileira de Ciências Criminais, v. 115, p. 195-219, jul./ago. 2015. Disponível em: <http:// rt-online.mppr.mp.br/maf/app/resultList/document? \&src=rl\&srguid=i0ad8181500000156094bdde2fe409b41\&docguid =I8b78deb0463a11e5bb51010000000000\&hitguid=I8b78deb0463a11e$5 \mathrm{bb} 51010000000000 \&$ spos $=1 \&$ epos $=1 \& \mathrm{td}=10 \&$ context $=22 \&$ startChunk $=1 \&$ endChunk $=1>$. Acesso em: 20 jul. 2016.

CÂMARA DOS DEPUTADOS. PL 2016/2015. Altera a Lei n 12.850, de 02 de agosto de 2013, e a Lei $\mathrm{n}^{\circ} 10.446$, de 08 de maio de 2002, para dispor sobre organizações terroristas. 18 jun. 2015. Disponível em: http://www.camara.gov.br/proposicoesWeb/fichadetramitacao?idProposicao $=1514014>$. Acesso em: 20 jul. 2016.

CAMPINHO, Bernardo Brasil. As Projeções Internacionais e Constitucionais dos Direitos Humanos e a Questão do Terrorismo. In: CONGRESSO NACIONAL DO CONPEDI, 19., 2010, Florianópolis. Anais... Florianópolis: Fundação Boiteux, 2010. p. 7098-7119.

CARVALHO, Salo de. Política de Guerra às Drogas na América Latina entre o Direito Penal do Inimigo e o Estado de Exceção Permanente. Crítica Jurídica, v. 25, p. 253-267, 2006. 
CONSELHO DE CONTROLE DE ATIVIDADES FINANCEIRAS. Ministério de Fazenda. 40 Recomendações GAFI. 15 maio 2015. Disponível em: <http://www.coaf.fazenda.gov.br/backup/pld-ft/ novos-padroes-internacionais-de-prevencao-e-combate-a-lavagem-de-dinheiro-e-ao-financiamento-do-terrorismo-e-da-proliferacao-as-recomendacoes-do-gafi-1>. Acesso em: 26 jan. 2016.

CORDEIRO, Carolina Souza. Mecanismo Alternativo da Ordem Democrática e o Terrorismo. In: ENCONTRO NACIONAL DO CONPEDI, 20., 2011, Belo Horizonte. Anais... Florianópolis: Fundação Boiteux, 2011. p. 6919-6932.

CRENSHAW, Marta. O Terrorismo Visto como um Problema de Segurança Internacioanl. In: HERZ, M.; AMARAL, A. B. do (Org.). Terrorismo e relações internacionais: perspectivas e desafios para o século XXI. Rio de Janeiro: Ed. PUC-Rio, 2010. p. 25-46.

DEPARTMENT OF DEFENSE. DoD Directive 2000.12. Protection of DoD Resources Against Terrorist Acts. June 16, 1986.

FATF - GAFI. Padrões internacionais de combate à lavagem de dinheiro e ao financiamento do terrorismo e da proliferação. As Recomendações do Gafi. fev. 2012. Disponível em: <http://www.coaf. fazenda.gov.br/links-externos/As\%20Recomendacoes\%20GAFI.pdf>. Acesso em: 22 fev. 2016.

FOUCAULT, Michel. Em Defesa da Sociedade. São Paulo: Martins Fontes, 2008a.

FOUCAULT, Michel. Segurança, Território e População. São Paulo: Martins Fontes, 2008b.

FRAGOSO, Heleno Claudio. Terrorismo e criminalidade política. Rio de Janeiro: Forense, 1981.

GREEN, James N. Apesar de vocês: oposição à ditadura brasileira nos Estados Unidos, 1964-1985. Tradução S. Duarte. São Paulo: Cia. das Letras, 2009.

GREEN, Penny; WARD, Tony. State crime-governments, violence and corruption. London: Pluto Press, 2004.

GROS, Fréderic. Estados de violência: ensaio sobre o fim da guera. Aparecida: Ideias \& Letras, 2009.

HALWANI, Haja. Terrorism: definition, justification, and applications. Social theory and practice. An International and Interdisciplinary Journal of Social Philosophy, University of Florida, n. 2, 2006.

HAYES, Ben. Counter-terrorism, 'policy laundering' and the FATF: legalising surveillance, regulating civil society. Amsterdã: Transnational Institute e Statewatch, 2012. Disponível em: <http://www. statewatch.org/news/2012/mar/tni-sw-fafp-exec-summary.pdf>. Acesso em: 03 jan. 2016.

HOBSBAWN, Eric. Globalização, democracia e terrorismo. São Paulo: Companhia das Letras, 2007.

HUGGINS, Martha K.; HARITOS-FATOUROS, Mika; ZIMBARDO, Philip G. Operários da violência: policiais torturadores e assassinos reconstroem as atrocidades brasileiras. Tradução Lólio Lourenço de Oliveira. Brasília, DF: Ed. UnB, 2006.

INTERNATIONAL CENTER FOR TRANSITIONAL JUSTICE. Parecer técnico sobre a natureza dos crimes de lesa-humanidade, a imprescritibilidade de alguns delitos e a proibição de anistias. Revista Anistia Política e Justiça de Transição, Brasília, DF, n. 1, p. 352-394, jan./jun. 2009. 
JAKOBS, Günther. Derecho penal del ciudadano y Derecho penal del enemigo. In: JAKOBS, Günther; CANCIO MELIÁ, Manuel (Org.). Derecho Penal del Enemigo. Madrid: Civitas, 2003.

LOCKE, John. Dois tratados sobre o governo. Tradução Julio Fischer. São Paulo: Martins Fontes, 1998.

MACHADO, Marta R. de Assis; GONÇALVES, Guilherme Leite. Por uma lei antiterrorismo de Estado. Ou não sobrará ninguém. Le Monde Diplomatique, São Paulo, 07 dez. 2015. Disponível em: <http://www.diplomatique.org.br/artigo.php?.id=2003>. Acesso em: 15 jan. 2016.

MACHIAVELLI, Niccolò. O príncipe. Tradução Sérgio Bath. In: Maquiavel O príncipe - Estudos. Curso de introdução à ciência política - estudo de caso. Brasília, DF: Ed. UnB, 1982.

MOVIMENTOS e intelectuais escrevem manifesto de repúdio à Lei Antiterror. MST, 01 out. 2015. Disponível em: <http://www.mst.org.br/2015/10/01/movimentos-e-intelectuais-escrevem-manifesto-de-repudio-a-lei-antiterror.html>. Acesso em: 02 jan. 2016.

NUNES JÚNIOR, Flávio Martins Alves et al. Leis penais especiais. 4. ed. São Paulo: RT, 2016. Disponível em: <https://proview.thomsonreuters.com/title.htmleredirect =true\&titleKey=rt\%2Fmonografias\%2F92127194\%2Fv4.2\&titleStage $=$ F\&titleAcct $=$ ia744d77900000151914eef3aad7c9161\#sl=0\&eid =cb9439eab797694026f2322f287e0f23\&eat =\%5Bbid\%3D\%221\%22\%5D\&p$\mathrm{g}=\& \mathrm{psl}=\mathrm{e} \& \mathrm{nvgS}=$ false\&tmp=629>. Acesso em: 20 jul. 2016.

NUNES, Leandro Gornicki. Constituição, contraditório e linguagem. Revista Brasileira de Ciências Criminais, v. 119, p. 75-101, mar./abr. 2016. Disponível em: < http://rt-online.mppr.mp.br/maf/ app/latestupdates $/$ document? \&src $=$ rl\&srguid $=\mathrm{i} 0 \mathrm{ad} 8181500000156094 \mathrm{da} 85683975 \mathrm{~d} 3 \mathrm{~d} \&$ docgui$\mathrm{d}=$ If9e6d31010e811e682c3010000000000\&hitguid =If9e6d31010e811e682c3010000000000\&spo$\mathrm{s}=13 \&$ epos $=13 \& \mathrm{td}=1165 \&$ context $=70 \&$ startChunk $=1 \&$ endChunk $=1>$. Acesso em: $20 \mathrm{jul}$. 2016.

PASSETTI, Edson. Ecopolítica: procedências e emergência. In: CASTELO BRANCO, Guilherme; VEIGA-NETO, Alfredo (Org.). Foucault: Filosofia \& Política. Belo Horizonte: Autêntica, 2011. p. 127-141.

PASSETTI, Edson. Terrorismos, Demônios e Insurgências. In: PASSETTI, E.; OLIVEIRA, S. (Org.). Terrorismos. São Paulo: Educ, 2006. p. 95-121.

PASSETTI, Edson. Terrorismos. In: PASSETTI, E. (Org.). Anarquismo urgente. Rio de Janeiro: Achiamé, 2007. p. 93-94.

PRESIDÊNCIA DA REPÚBLICA. Mensagem no 85, de 16 de março de 2016. Disponível em: <http:// www2.camara.leg.br/legin/fed/lei/2016/lei-13260-16-marco-2016-782561-veto-149753-pl.html>. Acesso em: 16 mar. 2016.

REDE JUSTIÇA CRIMINAL. Nota Técnica Contra o PL 2016/2015. 23 jul. 2015. Disponível em: <http://www.conectas.org/arquivos/editor/files/NOTA\%20T\%C3\%89CNICA\%20-\%20PL\%20 2016_2015_RJC.pdf>. Acesso em: 04 fev. 2016.

RODRIGUES, Thiago. Guerra e Terror. In: CASTELO BRANCO, Guilherme (Org.). Terrorismo de Estado. Belo Horizonte: Autêntica, 2013. p. 203-220.

RODRIGUES, Thiago. Segurança planetária, entre climático e o humano. Ecopolítica, n. 3, p. 5-41, 2012. 
SAFRANSKI, Rüdiger. iCuánta globalización podemos soportar? Barcelona: Tusquets, 2005.

SANFÉLIX-VIDARTE, Vicente. Terror e Globalização. In: CASTELO BRANCO, Guilherme (Org.). Terrorismo de Estado. Belo Horizonte: Autêntica, 2013. p. 83-105.

SENADO FEDERAL. Substitutivo do Senado ao Projeto de Lei da Câmara no 101, de 2015 (PL 2016, de 2015, na Casa de origem). 04 nov. 2015. Disponível em: <http://www.senado.leg.br/atividade/rotinas/materia/getPDF.asp? $\mathrm{t}=182344 \& \mathrm{tp}=1>$. Acesso em: 03 jan. 2016.

SILVA FILHO, José Carlos Moreira da. O Terrorismo de Estado e Ditadura Civil-Militar no Brasil: direito de resistência não é terrorismo. In: CONGRESSO NACIONAL DO CONPEDI, 20., 2011, Vitória. Anais... Florianópolis: Fundação Boiteux, 2011. p. 11328-11349.

TUMAN, Joseph. Communicating Terror: the rhetorical dimensions of terrorism. London: Sage Publications, 2010.

US PATRIOTIC ACT. Sec. 802, \2331. 2001.

ZAFFARONI, Eugenio Raul. El crimen de Estado como objeto de La Criminologia, 2006. Disponível em: <http://www.infojus.gob.ar/doctrina/dacf130247-zaffaroni-crimen_estado_como_objeto.htm >. Acesso em: 18 dez. 2015. Acesso em: 14 jan. 2016.

Data da submissão: 25 de julho de 2016 Avaliado em: 04 de setembro de 2016 (AVALIADOR A) Avaliado em: 23 de setembro de 2016 (AVALIADOR B) Aceito em: 12 de abril de 2017 
